\title{
Dentist successfully fights vicarious liability claim at Court of Appeal
}

Raj Rattan - a Dental Protection member and its dental director - has successfully challenged a vicarious liability claim at the Court of Appeal - an outcome that will benefit many practice owners in England and Wales.

The claim was brought by a client of the Dental Law Partnership (DLP) for treatment carried out by associate dentists at $\mathrm{Mr}$ Rattan's former practice - Mr Rattan did not carry out any of the patient's treatment.

Mrs Hughes, represented by DLP, pursued a claim against Mr Rattan under both vicarious liability and non-delegable duty of care, despite the fact that the treating dentists had been identified and remain willing to respond to the claim. DLP and their client refused to engage with them and instead pursued Mr Rattan as practice owner.

The preliminary hearing judgement in July 2021 made clear that Mr Rattan's conduct as a practice owner was not being criticised; however, it ruled that he was vicariously liable for the self-employed associate dentists working at his former practice and that he owed Mrs Hughes a non-delegable duty of care when she attended his practice for dental treatment.

While Dental Protection has extended its benefits for current and new practice principal members to include additional protection against vicarious liability and/or non-delegable duty of care claims relating to treatment provided by self-employed, contracted dental practitioners, it supported Mr Rattan in appealing the High Court judgement as a matter of principle.

Geoff Jones, Executive Director, Member Protection and Support, at Dental Protection said: 'we have supported Raj Rattan as a Dental Protection member in fighting this case which has significant repercussions for the dental profession. We are extremely pleased the judgement on vicarious liability has not been upheld and will now explore whether we can take the fight on nondelegable duty of care to the Supreme Court.

'These mostly unnecessary claims cause real distress for practice owners, some of whom have long since retired and pose a risk to the long-established arrangements that exist between practice owners and their associates.

'The self-employed dentists who were involved in the patient's care were willing to respond to the claim from the outset, but DLP and their client refused to engage with them. Mrs Hughes had nothing to gain by refusing to engage with the treating dentists and pursuing Mr Rattan personally.

'DLP has been pursuing a number of claims like this against the practice owner rather than the self-employed dentists who provided the treatment. In the majority of those cases, where a liability was established, the treating dentists are also willing to settle and the claimant could have received compensation much sooner.

'Now, due to the Court of Appeal decision in this case, many of these vicarious liability claims brought by DLP on behalf of their clients, may fail unless it can be shown that the practice owed them a non-delegable duty of care in relation to the treatment carried out by the treating dentists.

'We are carefully considering the implications of the Court's finding in relation to non-delegable duty of care and will provide further guidance to practice owners as soon as possible.

'While eligible Dental Protection practice principal members can request assistance with vicarious liability and nondelegable duty of care claims where they are named as the defendant, we remain committed to fighting them on behalf of members and the wider profession.

'If any Dental Protection practice principal members with an open vicarious liability case would like to discuss the implications of this judgement, they should contact their case handler.

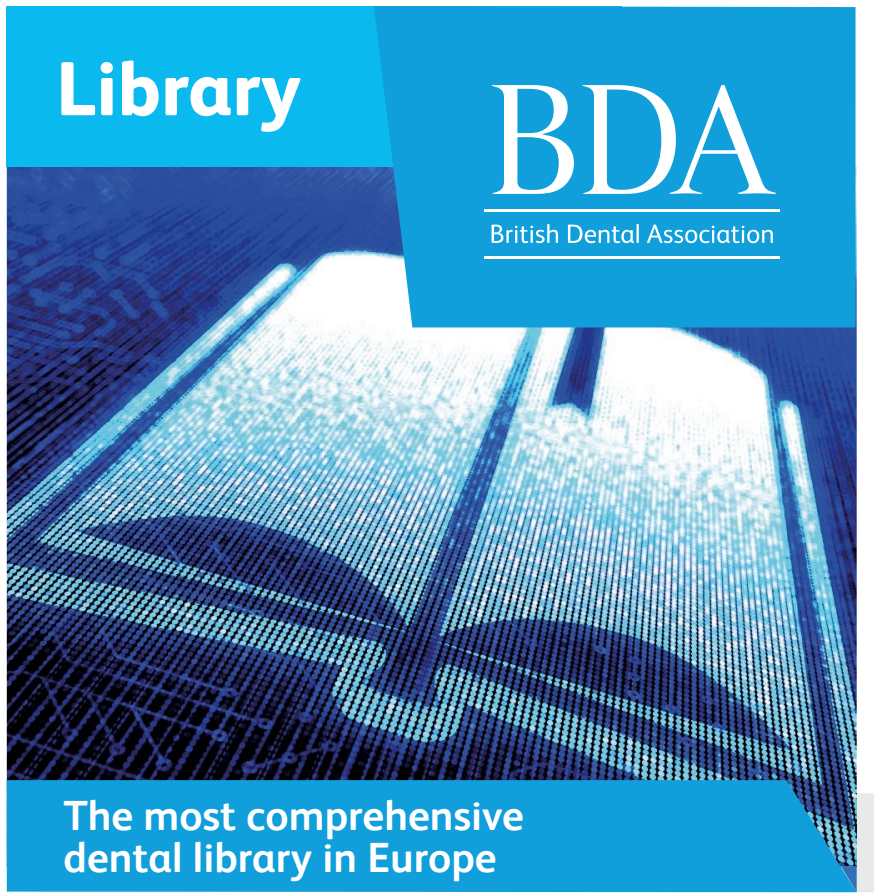

Members have free access to a range of library services:

- eBooks: go online and access over 500 ebooks, with 30 hours of CPD, saving you time and money

- eJournals: 15 titles to read online, download or print out

- Literature searches and document supply

- Virtual topic packages available on a range of dental subjects

- Specialist revision web bundles available on key topics.

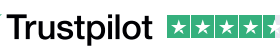

Stay connected bda.org/library

The BDA is owned and run by its members. We are a not-for-profit organisation all our income is reinvested for the benefit of the profession. 